\title{
Disaster Communication In New Media In Government Public Relations Perspectives
}

\author{
Rachmat Kriyantono \\ \{rachmat kr@ub.ac.id $\}$
}

Departments of Public Relations, Universitas Brawijaya

\begin{abstract}
This study aims to prove that there is a change in media coverage of the disaster along with the development of new media. Disaster is an event that has a wide impact for the community. Media is a public relations partner providing information to the public, ie as a source of information about disaster as a form of public information. It is assumed that the quality of disaster information reflects how public relations performs the role of information subsidies to the media. However, through a content analysis, research results show that disaster reporting is only informative and has not been able to educate and foster resilience for the community. This study contributes to disaster communication studies by proving that the change of media character from conventional to new media has not been matched by the increasing role of disaster reporting for the community. It also provide theoretical framework for public relations fields that the role of information subsidies regarding educational aspects of the disaster from the government public relations has not been fully performed to affect media agenda.
\end{abstract}

Keywords: Content analysis, Indonesia, disaster communication, new media

\section{Introduction}

In 2014 to 2016 there are 1062 disasters occurring in Indonesia with death toll of 201 and 1.7 million displaced persons [1]. The role of the media is so important, along with the fact that the Indonesian government is considered less responsive and ignores the anticipated disaster [1]. Communities are not fully aware of a disaster occurring or which will occur as well as anticipatory measures they must take from information reported by the media [2]. Communities have limitations to study disasters and a weak understanding of disasters so that every disaster becomes a new thing for society [2]. This leads a question: "how is the framing built by the mass media related to the news of the disaster?" In addition, public relations government is expected to function subsidized information to the media to educate the public as a function of serving the public interest [3]. Information subsidies are an attempt to reduce public uncertainty about disasters because of "information is power" [4]. It is assumed, the media needs information to be disseminated to the public and this requires the role of government public relations as a government spokesperson. 


\section{Literature review and formulating hypothesis}

The role of communication through media coverage is important because disaster is a situation that requires coordination of information and actions from various parties to be handled properly [2]. Media-filled information is required to contribute to the creation of affected communities to better prepare themselves in the future and rise from disaster problems [2]. On the other hand, the role of the media in disasters has been limited only as a source of information that dramatically describes the state of the disaster and often only focuses on disturbed normal circumstances, mutually helping and rescuing individuals, and institutions working to locate the cause of disasters without preaching any casualty explanations for the cause of the disaster [2]. Especially in the context of Indonesia, the media in Indonesia focus more on sensationality in preaching disaster by displaying images of vulnerable victims, such as women, children, and the elderly. Images on a story will provide concrete evidence of whether or not something happened. Based on Agenda Setting Theory [5], researchers assume that if the content of the media is a lot of sensationality then education about disaster is full of aspect of sensationality.

Other research was conducted by Ying and Wang [6] with critical linguistic and critical discourse analysis methods against the China Daily news relating to the Wenchuan earthquake that occurred in 2008. Ying and Wang found that all the news was politically motivated to show the open capabilities and access provided by public relations of the Chinese Communist Party to the media related to information and disaster management. Adopting McQuail [7] on the role of the media, it can be inferred from previous studies that the media play a more role as a window that invites the audience to see the environment, platforms that convey information, and barriers that cover the truth for certain interests. Educative roles such as interpreters that help the audience understand the experience, interactive communication that includes audience opinions, signposts that give instructions and instructions; filters that share experiences and focus on others, and mirrors that reflect the audience.

On the other hand, the media is now expanding with the emergence of new media consisting of computer-based technology [8]. Holmes [9] explains that the characteristics of new media as: 1) decentralization; 2) two way; 3) beyond the control of the situation; 4) democratization; 5) raising individual awareness; and 6) individual orientation. Littlejohn \& Foss [9] also saw the new media more interactive and created a new understanding of personal communication. The new media has provided an increasing number of entertainment and information options to transform society into potential content producers. New media make information open, flexible, dynamic, and encourage a democratic society. From the literature of this review it can be formulated hypotheses as follows: (1) Disaster news is informative, educating and fostering resilience for the community; (2) The frequency of news coverage only occurs when a disaster occurs.

\section{Research methods}

This research uses quantitative content analysis method, ie researching the content of news about flood disaster event in Garut, Indonesia. Researchers take all the news between September 20, 2016 and October 4, 2016. The time limit is fourteen days from the day of the disaster to the 14th day or the end of disaster evacuation by the Disaster Relief Team with the 
assumption and based on preliminary data that the frequency of news will be found during the evacuation period. There are 402 news that analyzed from 19 online news portals, ie (1) Antara News.Com, (2) Republika Online, (3) MetroTV News.com, (4) Liputan6.Com,(5) Okezone, (6) Detik, (7) Garut News, (8) Sukabumi Update, (9) Tempo, (10) Viva News, (11) Bola.Net, (12) VOA, (13) Kabar24, (14) Bintang, (15) Rima News, (16) BBC, (17) Tribun News, (18) Berita Satu, dan (19) Kompas.

The categorization used in coding data was adopted from Houston et al. (2012): Disaster effect; Disaster affected; Coverage frame; Event space; and event time. Through the frequency distribution table the researcher can find out the scores on each category and the score is calculated to see which categorization get the average high and low score. Intercoder reliability is used to see the level of approval of coders that researchers have used by coding (judge) [10].

\section{Results and discussion}

For disaster effect category, there are six subcategories whose frequency distribution value is above 5\% that is: (1) Death and accident $(19,52 \%)$, (2) Evacuation and transportation (19,26\%), (3) 18.49\%), (4) future development (12.07\%), (5) social support (10\%), and (6) political implications $(9,25 \%)$. It appears that the main focus reported by the media about a catastrophe is a matter of death or a casualty caused by a disaster.

The focus of media coverage on disaster-affected subjects can be seen through 11 subcategories (Figure 2). There are five sub-categories with a frequency distribution value above five percent: (1) Individual (42.71\%), frist responders (29.82\%), Government (5.86\%), Family $(5.19 \%)$, Anank-child $(5.19 \%)$. Of the five subcategories that have the highest frequency distribution value is the sub-category of Individuals.

The category of frame coverage illustrates all the major topics raised by the media in preaching disaster. Subcategories that have a frequency distribution value there are only three subcategories namely: (1) Human Interest (58.55\%), Environment (21.02\%), and Politics $(17.09 \%)$. Event space categories are used to view geographic location or impact of disaster. Based on the above frequency distribution data it can be seen that it is absolute that the news is loaded on a regional scale. This can be seen from the example of the news that indicate the geographic location of the disaster.

The last category used to map disaster prevention trends is event time. Disaster news often published is about the current state of the disaster (present) $(91.39 \%)$. Next, despite the far-reaching news that is published informs about the state of post-disaster handling $(6.56 \%)$. Finally, the smallest frequency distribution value is the preaching of disaster that informs the state before the disaster $(2.05 \%)$.

In this category the researcher shows the focus of media coverage by time. News content that contains pre-disaster conditions such as early warning, evacuation training, and other preventive measures, then the news is included in the event's past time category. Following this, if the content of the news story describes the situation at the time of the disaster, such as the current number of victims, the disaster condition, the evacuation actions during the disaster, then the news goes into the event time present category. Finally, news content that contains information about plans for handling any impacts from future disasters is included in the category of event time futures.

In the event time past the most loaded news items are about death, building damage, evacuation and transportation, political implications, future development, social support, and government services. It can be assumed that although the news event time is past but it is not a 
reference of media preparedness in dealing with disasters. Although in some news quotations there are sentences that indicate pre-disaster conditions such as damage to the Cimanuk River basin have occurred since 1980 but the news has only been issued during times of disaster and is accompanied by current information on disasters such as information on the number of casualties and environmental damage resulting from disaster. It also indicates that the media in Indonesia have not taken a preventive role in giving early warning to the community of possible disasters.

Therefore, based on the distribution of frequency distribution in the category of event time the highest subcategory is the event time present of $93.39 \%$. In the distribution of frequency distribution, the three most commonly reported news items are building damage $(20,419 \%)$, death $(13,813 \%)$, and evacuation and transportation $(13,098 \%)$. The data shows that the media is so fast in reporting the current state of the disaster. The main focus of news on the problem of damage caused by disasters, death, and the process of evacuation or rescue of disaster victims. In addition, the data in the above table also indicates that media coverage related to disasters is only done when the disaster is happening or means the media has not been able to provide preventive information in the form of education to the community to deal with the disaster.

Furthermore, in the last event time category that is past with the distribution of frequency distribution of $6.56 \%$, the three most widely reported news items are forward development (2.032\%), political implications (1.478\%), and damage to buildings (1.108\%). The empirical data provides an illustration that the media-related news coverage of disasters with event time futures explains the actions that will be undertaken by stakeholders to address post-disaster situations. Disaster effected future developments explain actions that will be done by the government for example to overcome the problems caused by the disaster. These actions are usually rules that fall within the subcategories of political implications. In the disaster report, the political implications issued by the government as a form of future development in the future post-disaster handling are (1) the designation of flats for the victims of banjir bandang disaster in Garut, (2) improvement of Cimanuk River flow, and (3) due to land conversion.

It can be concluded that the media in Indonesia have not been able to contribute in the preventive action proven event time in the most widely reported is the present focus on the problem of building damage, death, and evacuation. In addition, the portion of pre-disaster reporting is also very small.

The highest frequency distribution distribution scores found on the human interest coverage coverage with the disaster affected being individuals. The theme of death is the greatest theme in human interest. The second highest frame coverage is the environment with the individual news subject, however, the impact experienced by the individual on the second frame coverage is about the safety in the evacuation process being carried out. The third frame coverage is politics with the most reporting subjects as well as individuals but the concentration is on the problem of building damage associated with refugee relocation policies and the provision of new shelters for refugees. The fourth frame coverage is an economic problem related to the future developmental issues of human welfare.

The highest frame coverage is human interest which shows that the main focus of news related to humanitarian issues such as human welfare issues and disaster history. In this coverage frame, there are five most popular news objects, namely death $(12,643 \%)$, evacuation $(12,049 \%)$, building damage $(11,115 \%)$, social support $(7,976 \%)$, and forward development $(7.042 \%)$. Humanitarian values are the main focus in disaster news with the main object of news is about information about death and followed by human welfare problem which is represented by generating information about evacuation process and social support 
and forward handling that focus in solving the problem of building damage. Data showing that human interest into the highest frame coverage also indicates that the media in the process of preaching the disaster has not been able to deliver educational messages to the community to face the future disaster situation or the concept of media has not been able to create resilience attitude to the community.

Next, the second largest frame coverage used by media to pack the news is the environment with the distribution of frequency distribution of $21.02 \%$ or half of the distribution of human interest coverage. In the environmental frame coverage the three most widely reported news items are evacuation $(4.795 \%)$, death $(4.795 \%)$, and damage to buildings $(4,635 \%)$. In the coverage framework of the news coverage carried out by the media regarding humanitarian issues, environmental development, the effects of disasters on the natural environment, hazards, health, diseases, and security during disasters.

The main issues discussed in news with environmental coverage frames are humanitarian problems namely evacuation, and damage to buildings. In disaster effected evacuation, also discussed about the safety in evacuation process by raising weather prediction and calculation of the possibility of occurrence of flood disaster following in Garut. Similarly, human interest coverage in the media frame coverage of the media also does not contain educational information to the public regarding the actions that should be done by the community in pre and post disaster conditions.

Coverage of political frame has the value of distribution of frequency equal to $17,09 \%$ with three highest reporting object that is political implication $(4,354 \%)$ damage of building $(2,693 \%)$, and evacuation $(2,573 \%)$. Coverage of the political frame means that media coverage is concerned with governance, leadership, rules and politics issues in disaster situations. Referring to the existing empirical data, it can be considered that the political implications that many of the media present in the news related to the decisions or policies in the problem of damage to the building mentioned will be the relocation of refugees to the flats that have been prepared by the government and the evacuation policy related to disaster evacuation time. Other political implications that arise in news such as education assistance, disbursement of funds for disaster relief, investigation of causes, and other things related to the recovery of the post-disaster situation.

Finally, for the disaster effected, the smallest value on the economic frame coverage with the total frequency distribution is $2.55 \%$ with the three most reporting objects i.e. building damage $(0,637 \%)$, cost of disasters $(0.318 \%)$, and evacuation $(0.382 \%)$. The empirical data shows that in the circumstances of economic problems it is not the main focus of news although the object is the most widely reported is the problem of building damage. When compared with the other three coverage frames then the highest building damage is loaded in news with human interest coverage frame. Nevertheless, in the economic frame coverage there is also a news item about the cost of disaster that contains about the material lose that must be borne by the disaster.

It can be concluded that the highest frame coverage used by the media to proclaim disaster is human interest with the object of news about the damage of buildings, death, and evacuation. The content of news published by the media in a state of disaster is only informative and has not been educative yet has not been able to build a resilience attitude to the community. But that does not mean that informative content is not important. Because the news media is the main reference for the community when there is a disaster, the media can actually deliver educational messages related to actions that can be done by the community in a state of disaster, disaster and post-disaster, the community can determine the post-disaster preventive and recovery posture right. 
The hypothesis of this study can not be fully accepted. Although the media coverage in Indonesia related to the disaster is informative, but, has not been able to provide education and foster resilience attitude for the community. The informative nature of the media is indicated through the subject and the object of its preaching. The reporting subject has much to do with the impacts of disasters on affected individuals who have been impacted by calamity, damage to buildings, and evacuations. This becomes an important note that in disaster state the media is expected to not only be informative but also educative and able to foster resilience attitude toward society for disaster happened.

The second hypothesis can be accepted, namely the media coverage in Indonesia related to disaster only focus on the time of disaster. This is evidenced by the amount of news on event time present has the highest frequency distribution. Although there is some news that falls into the category of event time past but it does not show a media preventive effort in the form of early warning to the community because the review of conditions before the disaster was issued during the disaster. In addition, regarding the growth of resilience attitudes for the media community can increase the frequency of news on event time future. This is because in the event time futures media role to provide information that is building on the community affected by the disaster.

\section{Conclusion}

Based on these two hypotheses, it can be concluded that it is necessary to design a disaster reporting model that fulfills the media's responsibility to be able to educate and cultivate a resilience attitude toward the community. The design of news models that can be done is in the pre-disaster state media can map the potential-disaster disaster that will occur in each region this is an educational function. Then, when disaster occurs the media serves as a medium of information. Next, in the post-disaster state media play a role as a media through its news is expected to build a resselince attitude for society.

From public relations perspectives, it also provide theoretical framework for public relations fields that the role of information subsidies regarding educational aspects of the disaster from the government public relations has not been fully performed to affect media agenda.The object of this study is limited in one disaster event so that the results can not fully represent the state of disaster-related media coverage. The researcher recommends: (1) conducting a quantitative test of the design of news model presented as the result of this research. (2) Conducting a similar study but with the number of disaster cases more eg in the case of disasters that hit Indonesia ten years. (3) Doing newsromm studies to be able to verify the design of disaster reporting model found in this research.

\section{References}

[1] Mardiansyah, W.: Tahun ini potensi bencana di indonesia masih tinggi. Metrotv News.com. Accessed from http://news.metrotvnews.com/peristiwa/ybJ8QpWKtahun-ini-potensi-bencana-di-indonesia-masih-tinggi. (20 Juni 2016)

[2] Murphy, E.R.: Developing disaster preparedness education via broadcast media and community involvement (Dissertation). Universitas Jyvaskila, Timo Hautala. (2014).

[3] Cutlip, M. S, Allen H. C., \& Broom, G.M. Effective Public Relations. (2011). 
[4] Kriyantono, R.: Teori Public Relations. Jakarta: Prenada (2017).

[5] Griffin, E.M.: A first look at communication theory. New York: McGraw Hill. (2013).

[6] Yin, L., \& Wang, H.: People-centered myth: representation of the wenchuan earthquake in china daily. Discourse \& Communication, 4 (4), 383-398. (2010).

[7] McQuail, D.: Mass communication Theory. California: Sage Publications. (2010).

[8] West, R. \& Turner, L. H.: Introducing communication theory: Analysis and application. Jakarta: Salemba Humanika. (2010).

[9] Littlejohn, S. W. \& Foss, K. A.: Theories of Human Communication. Jakarta: Salemba Humanika. (2014].

[10] Kriyantono, R.: Teknik Praktis Riset Komunikasi. Jakarta: Prenada (2014). 